\title{
Postwildfire Preliminary Debris Flow Hazard Assessment for the Area Burned by the 2011 Las Conchas Fire in North-Central New Mexico
}

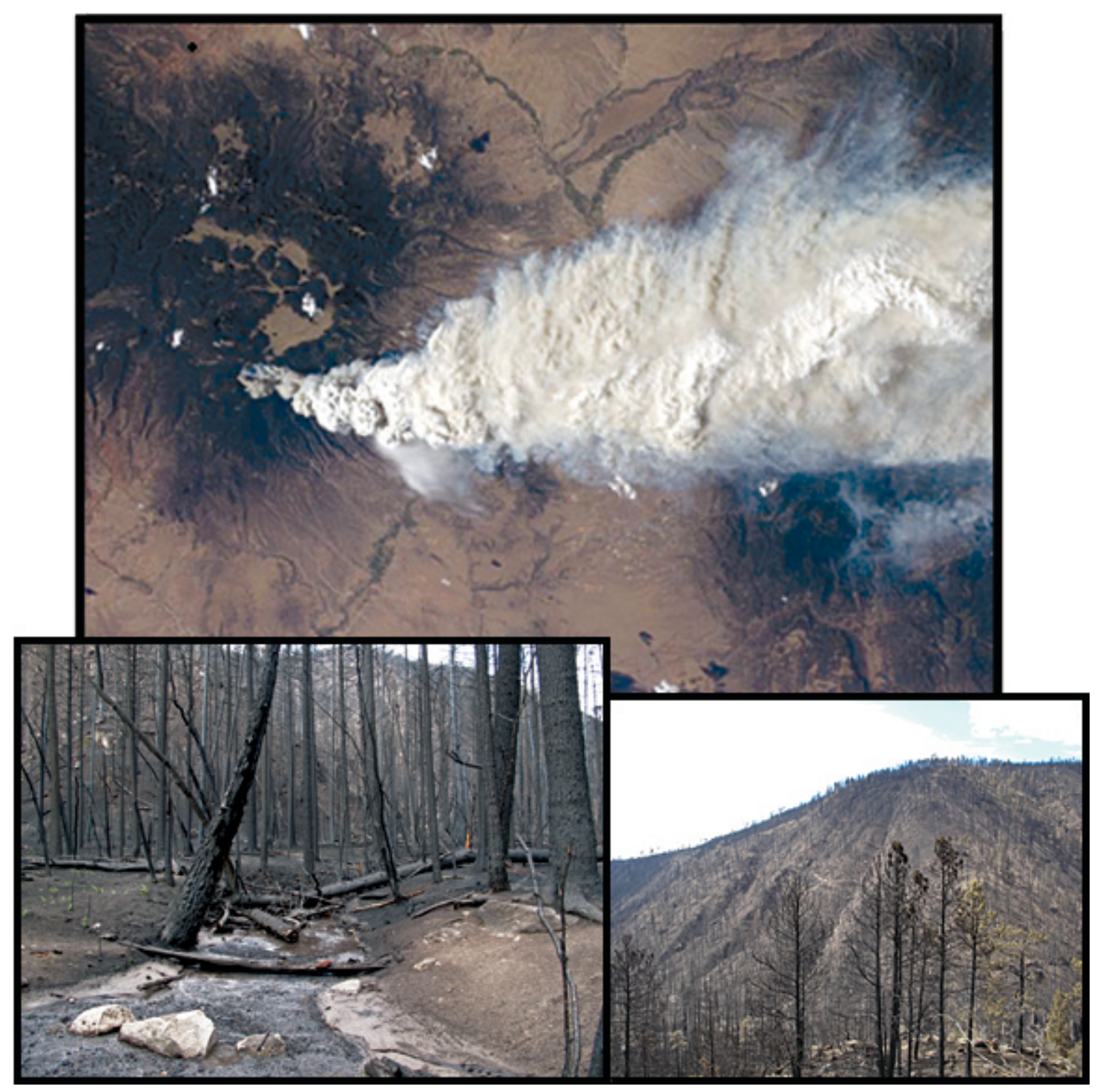

Open-File Report 2011-1308

U.S. Department of the Interior

U.S. Geological Survey 


\section{Postwildfire Preliminary Debris Flow Hazard Assessment for the Area Burned by the 2011 Las Conchas Fire in North-Central New Mexico}

By Anne C. Tillery, Michael J. Darr, Susan H. Cannon, and John A. Michael

Open-File Report 2011-1308

U.S. Department of the Interior

U.S. Geological Survey 


\section{U.S. Department of the Interior \\ KEN SALAZAR, Secretary}

\section{U.S. Geological Survey \\ Marcia K. McNutt, Director}

U.S. Geological Survey, Reston, Virginia: 2011

For more information on the USGS-the Federal source for science about the Earth,

its natural and living resources, natural hazards, and the environment-visit

http://www.usgs.gov or call 1-888-ASK-USGS

For an overview of USGS information products, including maps, imagery, and publications, visit $h t t p: / / w w w . u s g s . g o v / p u b p r o d$

To order this and other USGS information products, visit http://store.usgs.gov

Suggested citation:

Tillery, A.C., Darr, M.J., Cannon, S.H., and Michael, J.A., 2011, Postwildfire preliminary debris flow hazard assessment for the area burned by the 2011 Las Conchas Fire in north-central New Mexico: U.S. Geological Survey Open-File Report 2011-1308, 11 p.

Frontispiece: Satellite view of Las Conchas Fire (photos by NASA), canyon slopes burned in Bandelier National Monument (photo by National Park Service), valley floor of areas burned in Bandelier National Monument (photo by National Park Service).

Although this report is in the public domain, permission must be secured from the individual copyright owners to reproduce any copyrighted material contained within this report. 


\section{Contents}

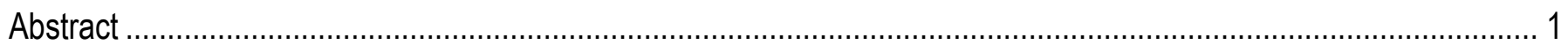

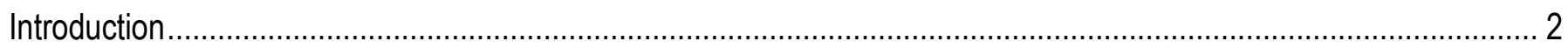

Methods Used to Estimate Debris Flow Hazards..................................................................................... 3

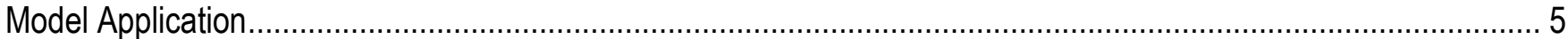

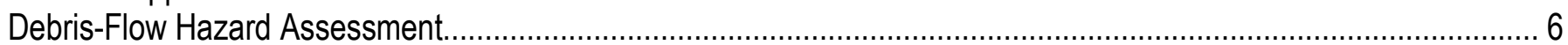

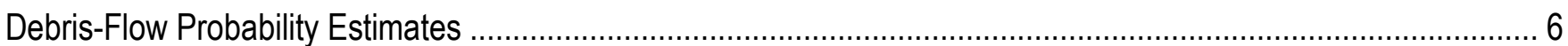

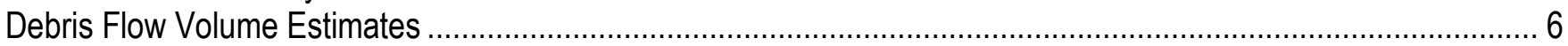

Combined Relative Debris Flow Hazard Rankings..............................................................................

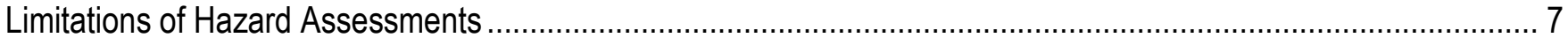

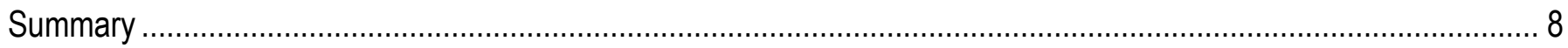

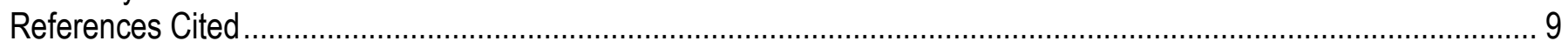

\section{Plates}

Plate 1. Estimated Probability of Postwildfire Debris Flows in the 2011 Las Conchas Fire Burn Area, North-central New Mexico ........................................................................................................ link

Plate 2. Estimated Volumes of Postwildfire Debris Flows in the 2011 Las Conchas Fire Burn Area, North-central New Mexico ........................................................................................................ link

Plate 3. Combined Probability and Volume Relative Hazard Ranking of Potential Postwildfire Debris Flows in the 2011 Las Conchas Fire Burn Area, North-central New Mexico link 


\section{Conversion Factors}

\begin{tabular}{lcl}
\hline \multicolumn{1}{c}{ Multiply } & By & \multicolumn{1}{c}{ To obtain } \\
\hline millimeter $(\mathrm{mm})$ & 0.03937 & inch (in.) \\
meter $(\mathrm{m})$ & 3.281 & foot $(\mathrm{ft})$ \\
kilometer $(\mathrm{km})$ & 0.6214 & mile $(\mathrm{mi})$ \\
\hline & Area & \\
\hline hectare $($ ha) & 2.471 & acre \\
square kilometer $\left(\mathrm{km}^{2}\right)$ & 247.1 & acre \\
square meter $\left(\mathrm{m}^{2}\right)$ & 10.76 & square foot $\left(\mathrm{ft}^{2}\right)$ \\
square kilometer $\left(\mathrm{km}^{2}\right)$ & 0.3861 & square mile $\left(\mathrm{mi}^{2}\right)$ \\
\hline & Volume & \\
\hline cubic meter $\left(\mathrm{m}^{3}\right)$ & 35.31 & cubic foot $\left(\mathrm{ft}^{3}\right)$ \\
\hline & Flow rate & \\
\hline millimeter per hour $(\mathrm{mm} / \mathrm{hr})$ & 0.03937 & inch per hour $(\mathrm{in} / \mathrm{hr})$ \\
\hline
\end{tabular}

Vertical coordinate information is referenced to the North American Vertical Datum of 1988 (NAVD 88). Horizontal coordinate information is referenced to the North American Datum of 1983 (NAD 83). 


\title{
Postwildfire Preliminary Debris Flow Hazard Assessment for the Area Burned by the 2011 Las Conchas Fire in North-Central New Mexico
}

\author{
By Anne C. Tillery, Michael J. Darr, Susan H. Cannon, and John A. Michael
}

\begin{abstract}
The Las Conchas Fire during the summer of 2011 was the largest in recorded history for the state of New Mexico, burning 634 square kilometers in the Jemez Mountains of north-central New Mexico. The burned landscape is now at risk of damage from postwildfire erosion, such as that caused by debris flows and flash floods. This report presents a preliminary hazard assessment of the debris-flow potential from 321 basins burned by the Las Conchas Fire. A pair of empirical hazard-assessment models developed using data from recently burned basins throughout the intermountain western United States was used to estimate the probability of debris-flow occurrence and volume of debris flows at the outlets of selected drainage basins within the burned area. The models incorporate measures of burn severity, topography, soils, and storm rainfall to estimate the probability and volume of debris flows following the fire.

In response to a design storm of 28.0 millimeters of rain in 30 minutes (10-year recurrence interval), the probabilities of debris flows estimated for basins burned by the Las Conchas Fire were greater than 80 percent for two-thirds (67 percent) of the modeled basins. Basins with a high (greater than 80 percent) probability of debris-flow occurrence were concentrated in tributaries to Santa Clara and Rio del Oso Canyons in the northeastern part of the burned area; some steep areas in the Valles Caldera National Preserve, Los Alamos, and Guaje Canyons in the east-central part of the burned area; tributaries to Peralta, Colle, Bland, and Cochiti canyons in the southwestern part of the burned area; and tributaries to Frijoles, Alamo, and Capulin Canyons in the southeastern part of the burned area (within Bandelier National Monument). Estimated debris-flow volumes ranged from 400 cubic meters to greater than 72,000 cubic meters. The largest volumes (greater than 40,000 cubic meters) were estimated for basins in Santa Clara, Los Alamos, and Water Canyons, and for two basins at the northeast edge of the burned area tributary to Rio del Oso and Vallecitos Creek.

The Combined Relative Debris-Flow Hazard Rankings identify the areas of highest probability of the largest debris flows. Basins with high Combined Relative Debris-Flow Hazard Rankings include upper Santa Clara Canyon in the northern section of the burn scar, and portions of Peralta, Colle, Bland, Cochiti, Capulin, Alamo, and Frijoles Canyons in the southern section of the burn scar. Three basins with high Combined Relative Debris-Flow Hazard Rankings also occur in areas upstream from the city of Los Alamos - the city is home to and surrounded by numerous technical sites for the Los Alamos National Laboratory.

Potential debris flows in the burned area could affect the water supply for Santa Clara Pueblo and several recreational lakes, as well as recreational and archeological resources in Bandelier National Monument. Debris flows could damage bridges and culverts along State
\end{abstract}


Highway 501 and other roadways. Additional assessment is necessary to determine if the estimated volume of material is sufficient to travel into areas downstream from the modeled basins along the valley floors, where they could affect human life, property, agriculture, and infrastructure in those areas. Additionally, further investigation is needed to assess the potential for debris flows to affect structures at or downstream from basin outlets and to increase the threat of flooding downstream by damaging or blocking flood mitigation structures. The maps presented here may be used to prioritize areas where erosion mitigation or other protective measures may be necessary within a 2- to 3-year window of vulnerability following the Las Conchas Fire.

\section{Introduction}

Debris flows have been documented after many fires in the western United States (Cannon and others, 2007; Cannon and others, 2009; DeGraff and others, 2011). The net result of rainfall on burned areas is often the transport and deposition of large volumes of sediment, both within and down-channel from burned areas. The rapid transport of large amounts of material makes debris flows particularly dangerous. In addition, debris flows following wildfire can occur in places where flooding or sedimentation has not been observed in the past, and can be generated in response to low-magnitude rainfall.

Under unburned conditions, the vegetation canopy, soil-mantling litter and duff, and soil serve to capture and store rainfall, which results in relatively little or no runoff. Postwildfire hydrologic response is affected by a decrease in vegetation cover and altered soil properties. Wildfires can consume rainfall-intercepting canopy, litter, and duff (Moody and Martin, 2001a, 2001b; Meyer, 2002; Cannon and Gartner, 2005). Water-repellent qualities in some soils can be enhanced or induced by the intense heat of a wildfire (DeBano, 1981; Doerr and others, 2000; Letey, 2001; Woods and others, 2006) and increased overland flow and erosion can occur (Wells, 1987; Moody and Martin, 2001a, 2001b). The presence of fine ash, which may expand when wetted, can block soil pore spaces and further reduce infiltration of water (Romkens and others, 1990; Woods and others, 2006). After a wildfire, the watershed response to rainfall events can be considered to shift, in general terms, from an infiltration-dominated to a runoff-dominated response (Cannon and others, 2009). Because of reduced soil infiltration, rainfall on wildfire burn scars can run off almost immediately as overland flow. This runoff in low-order channels can erode surficial materials, and with flow through the drainage network, rainfall can generate runoff that is rich in ash, soil, boulders, and dislodged vegetation. As additional sediment is entrained, sediment-laden flow in channels can progressively transition into debris flows that can affect lives, property, infrastructure, aquatic habitats, and water supplies (Cannon and Gartner, 2005). Debris flows are most frequent within 2 to 3 years after wildfires, when vegetative cover is absent or reduced and abundant materials are available for erosion and transport (Cannon and Gartner, 2005; Cannon and others, 2009).

Some of the areas burned by the 2011 Las Conchas Fire had previously been burned by the La Mesa Fire in 1977, the Dome Fire in 1996, and the Cerro Grande Fire in 2000. Previous investigations in these areas had found debris flows in some areas (Cannon and Reneau, 2000; Gartner and others, 2005) and increased peak flow from flood events (Veenhuis, 2002) especially in the 2 to 3 years following the fires. Data from the Cerro Grande fire contained in Cannon and others (2003) supports wildfire-related debris-flow generation through sedimentbulking processes. The debris flows documented in these areas tended to occur in basins with rugged morphologies, steep slopes, and soils derived from colluvium and loosely consolidated 
ash and volcaniclastic materials. Due to the low relatively density of pumice (less than that of water), pumice-rich debris tends to be transported by runoff without fine sediment bulking. Pumice-rich debris is therefore not highly susceptible to debris flows (Cannon and Reneau, 2000).

In June and July 2011, the Las Conchas Fire burned 156,593acres or 634 square kilometers $\left(\mathrm{km}^{2}\right)$ in the Jemez Mountains of north-central New Mexico (InciWeb, 2011) (Plate 1). The fire was the largest in recorded history of the state of New Mexico, and burned areas upstream from the City of Los Alamos and Los Alamos National Laboratory. Numerous bridge and culvert crossings on New Mexico State Highway 4 and others roadways may have been impacted by the effects of postwildfire flooding and or debris flows. Portions of land owned by the Pueblos of Cochiti (downstream from Cochiti Canyon), Jemez (at the southern extent of the burn area), and Santa Clara (in Santa Clara Canyon) were burned; these portions include the watersheds of lakes and springs used for water-supply and recreation in the Pueblo of Santa Clara. Recreational trails and archeological sites within Bandelier National Monument were also burned along with Santa Fe National Forest land, portions of the Valles Caldera National Preserve, and private lands. Downstream from the burned areas on valley floors approaching the Rio Grande are agricultural lands, the Visitor's Center of Bandelier National Monument, and the Village of Santa Clara (12 miles downstream of the burn perimeter in Santa Clara Canyon). Cochiti Lake is on the Rio Grande downstream from the burned area. Affected watersheds include the Rio Grande to the east and the Jemez River to the west of the burn area.

The burned area extends across several landscape types, from the flat valleys of the Valle Grande at nearly 9,000 feet (ft) in elevation, eastward over mountainous areas of the Sierra de los Valles, across the Pajarito Plateau with its rugged finger-mesa and canyon topography, and down to elevations below 6,000 ft near the Rio Grande (Plate 1). Concentrated areas of high burn severity occurred near Bland, Frijoles, and Santa Clara Canyons on the Pajarito Plateau.

The geology of the area is a complex assemblage of late Tertiary and Quaternary extrusive volcanic rocks and locally derived volcanic and volcaniclastic rocks, including welded and non-welded tuffs, pumice, fanglomerates, siliceous lava flows and domes (Smith and others, 1970; Kempter and Kelley, 2002; Goff and others, 2002, 2005). Loosely consolidated ash, volcaniclastic materials, and colluvium may be susceptible to debris flows on the Pajarito Plateau (Cannon and Reneau, 2000).

The area burned by the Las Conchas Fire is now at risk of substantial postwildfire erosion, such as that caused by debris flows and flash floods. The purpose of this report is to present a preliminary hazard assessment of the debris-flow potential for basins burned by the 2011 Las Conchas Fire.

\section{Methods Used to Estimate Debris Flow Hazards}

For this preliminary hazard assessment, a pair of empirical models was used to estimate the probability, volume, and combined relative hazard ranking of a debris flow from individual drainage basins in response to a given storm event in the Jemez Mountains of north-central New Mexico. The model for predicting debris-flow probability was developed by Cannon and others (2009) using logistic multiple-regression analyses of data from 388 basins in 15 burned areas in the intermountain western United States. Conditions in each basin were quantified using several readily obtained measures of areal burned extent, basin gradient, soil properties, and storm rainfall. Statistical analyses were used to identify the variables that most strongly influenced 
debris-flow occurrence and to build the predictive model. Equation 1 is used to calculate debrisflow probability (Cannon and others, 2009):

$$
P=e^{x} /\left(1+e^{x}\right)
$$

where,

$P$ is the probability of debris-flow occurrence in fractional form; and

$e^{x}$ is the exponential function where $e$ represents the mathematical constant.

Equation 2 is used to calculate $\mathrm{x}$ :

$$
x=-0.7+0.03(\% S G 30)-1.6(R)+0.06(\% A B)+0.07(I)+0.2(\% C)-0.4(L L),
$$

where,

$\% S G 30$ is the percent of the drainage basin area with slope equal to or greater than 30 percent;

$R$ is drainage basin ruggedness, the change in drainage basin elevation (in meters) divided by the square root of the drainage basin area (in square meters) (Melton, 1965);

$\% A B$ is the percentage of drainage basin area burned at moderate and high severity;

$I$ is average storm intensity (the total storm rainfall divided by the storm duration, in millimeters per hour);

$\% C$ is the percent clay content of the soil; and

$L L$ is the liquid limit of the soil (the percent of soil moisture by weight at which soil begins to behave as a liquid).

A second statistical model was used to estimate the volume of material that could issue from a basin mouth in response to a given storm. This model was developed using multiple linear-regression analyses of data compiled from 56 debris-flow-producing basins burned by eight fires (Cannon and others, 2009). Debris-flow volume measurements were derived from records of the amount of material removed from sediment-retention basins and from field measurements of the amount of material eroded from the main channels within a burned drainage. Statistical analyses were used to identify the variables that most strongly influenced debris-flow volume. The model provides estimates of the volume of material that may pass through a drainage-basin outlet in response to a single rainstorm event. The model has the form:

$$
\operatorname{Ln}(V)=7.2+0.6(\operatorname{Ln}(S G 30))+0.7(A B)^{0.5}+0.2(T)^{0.5}+0.3
$$

where,

$V$ is the debris-flow volume (in cubic meters);

$\mathrm{Ln}$ is the natural log function;

$S G 30$ is the area of drainage basin with slopes equal to or greater than 30 percent (in square kilometers);

$A B$ is the drainage basin area burned at moderate and high severity (in square kilometers);

$T$ is the total storm rainfall (in millimeters); and

0.3 is a bias correction factor that changes the predicted estimate from a median to a mean value (Cannon and others, 2009; Helsel and Hirsch, 2002). 
Debris-flow hazards from a given basin can also be represented by a "Combined Relative Debris-Flow Hazard Ranking" that is based on a combination of both probability of occurrence and volume (Cannon and others, 2009). For example, the most hazardous basins will have both the highest probabilities of occurrence and the largest estimated volumes of material. Slightly less hazardous would be basins that show a combination of either relatively low probabilities and larger volume estimates or high probabilities and smaller volume estimates. The lowest relative hazard basins would show both the lowest probabilities and the smallest volumes are identified. For this assessment, the estimated values of debris-flow probability and volume are categorized into relatively ranked classes, and these classes are added together to calculate a "Combined Relative Debris-Flow Hazard Ranking." This ranking identifies a possible range of responses from basins that are most prone to producing debris flows with the largest volumes to basins with the lowest probabilities that will produce the smallest events (Cannon and others, 2009).

\section{Model Application}

The two models were implemented for the Las Conchas Fire by first delineating 321 basins to be evaluated within the burned perimeter. The basins were delineated analyzing topographic information derived from 10-meter $(\mathrm{m})$ digital elevation models (DEMs) (USGS, 2011) with geographic information system (GIS) hydrological tools. Basin outlets (or pour points) were positioned at breaks in slope along mountain fronts, along drainages, and at the burned perimeter. Each basin to be evaluated was identified by a single outlet (pour point) located at the basin mouth, and conditions within the basin area upstream from that pour point were used to estimate debris-flow probability and volume (Cannon and others, 2009). Basin number assignments shown on Plates 1 through 3 are a function of the process used to place the basin pour points. Basin areas for analyzed basins averaged $1.2 \mathrm{~km}^{2}$ and ranged between $0.10 \mathrm{~km}^{2}$ and $7.6 \mathrm{~km}^{2}$ - these measurements are comparable to the basin sizes used in the development of the predictive models. The total area of the basins modeled was $394 \mathrm{~km}^{2}$, about two-thirds of the entire burned area. Some basins were not modeled if they exhibit broad, flat morphologies (such as some in the Valles Caldera National Preserve area). In order to provide more detail in areas within the steep, narrow canyons of the Pajarito Plateau, smaller watersheds that are tributary to the main canyons were modeled individually, instead of the entire length of the steep, narrow valleys along the canyon floors being considered.

Measures of the physical properties of soils within each basin were obtained from the State Soil Geographic (STATSGO) database (Schwartz and Alexander, 1995). If more than one soil unit occurred within a given basin, a spatially weighted average of the soil variable values was calculated. In basins burned by the Las Conchas Fire, the average clay content of soil was 16 percent (ranging from 12 percent to 32 percent) and the average liquid limit was 27 percent (ranging from 23 percent to 42 percent).

The Burned Area Emergency Response (BAER) Image Support Team of the U.S. Geological Survey Earth Observation and Science Center (EROS) and the U.S. Department of Agriculture Forest Service (USDAFS) Remote Sensing Applications Center (RSAC) provided a map of Burned Area Reflectance Classification (BARC), which was used as an indicator of the distribution of burn severity within the fire perimeter (U.S. Department of Agriculture Forest Service, 2011). The BARC map for the Las Conchas fire shows that the moderate and high burnseverity areas totaled $264 \mathrm{~km}^{2}$, which is 42 percent of the total burned area of $634 \mathrm{~km}^{2}$. The basins selected for modeling encompassed $200 \mathrm{~km}^{2}$ of moderate and high burn-severity areas where slope, watershed configuration, and topographic setting indicated susceptibility to 
debris-flow processes or where proximity to development indicates a vulnerability to hazards presented by debris flows.

Postwildfire debris flows in the intermountain western United States are often triggered in response to short-duration, high-intensity thunderstorms. Cannon and others (2008) found that most debris flows are triggered in response to storms with short recurrence intervals (from 2 to 10 years), and Kean and others (2011) demonstrated that periods of intense rain in less than 30 minutes were most likely to generate postwildfire debris flows. To characterize the effects of these rainfall conditions, the probability that a given basin could produce debris flows and the volume of a possible debris flow at the basin outlet that would result from a 30-minute-duration, 10-year-recurrence rainstorm of 28.0 millimeters $(\mathrm{mm})(56.0$ millimeters per hour $(\mathrm{mm} / \mathrm{hr}))$ were estimated. Precipitation data was used from Bonnin and others (2006) for weather stations at the City of Los Alamos and at Bandelier National Monument, N. Mex. Any storm with a 10-yearrecurrence interval is considered to have a 10 percent chance of occurring in any given year. This design storm was selected to represent a relatively significant storm event of sufficient intensity to produce debris flows.

\section{Debris-Flow Hazard Assessment}

The hazards of debris flows from basins burned by the Las Conchas Fire were assessed by estimating the probability of occurrence, by estimating the volume of potential debris flows, and by combining the probability and volume into a relative hazard ranking.

\section{Debris-Flow Probability Estimates}

In response to the design storm, modeling indicated that two-thirds (67 percent) of the basins have high probabilities of debris-flow occurrence (greater than or equal to 80 percent; Plate 1). Basins in the northern part of the burned area with a high probability of debris flow occurrence were concentrated in tributaries to Santa Clara Canyon but also include basins tributary to the Rio del Oso and basins entirely contained in the Valles Caldera National Preserve. In the central part of the burned area, basins tributary to Los Alamos and Guaje Canyons also showed high probabilities of debris flow occurrence, as well as tributaries to Peralta, Colle, Bland, and Cochiti Canyons in the southwest part of the burned area, and tributaries to Frijoles, Alamo, and Capulin Canyons in the southeast part of the study area. These high values of debris-flow occurrence reflect the combined effects of the basins being nearly completely burned at high and moderate severities and the steep slopes within these basins. Debris flows generated from these basins may directly affect the Pueblo of Santa Clara, sections of State Highway 4, and archeological sites in Bandelier National Monument and other areas. Sites such as the City of Los Alamos and Cochiti Lake may also be affected by indirect effects of debris flows occurring in burned areas upstream.

\section{Debris Flow Volume Estimates}

The debris-flow volumes estimated in this assessment (Plate 2) are independent of the estimated debris-flow probabilities. As a result, basins with high predicted debris-flow probabilities present a range of high to low threats to areas downstream, depending on the predicted volume of material mobilized in a debris flow. Estimated debris-flow volumes ranged from $400 \mathrm{~m}^{3}$ to greater than $72,000 \mathrm{~m}^{3}$, and the average estimated debris flow volume for all 321 basins modeled is $6,900 \mathrm{~m}^{3}$. Drainage basins with relatively large estimated volumes (over 
$10,000 \mathrm{~m}^{3}$ ) include tributaries to Santa Clara Canyon, Rio del Oso, Vallecitos Creek, and Arroyo de la Plaza Larga in the northern part of the burn area; tributaries to Guaje, Water, and Los Alamos Canyons in the central section of the burn area; and tributaries to Peralta, Colle, Bland, Cochiti, Capulin, Alamo, and Frijoles Canyons in the southern part of the burn area. Five basins have estimated debris-flow volumes greater than $40,000 \mathrm{~m}^{3}$, and include tributaries to Santa Clara Canyon (basin number 266), basins in Water Canyon and Los Alamos Canyon (numbers 10 and 310), and a basin tributary to Vallecitos Creek at the north end of the burned area (basin 235). The largest predicted debris flow volume of $72,400 \mathrm{~m}^{3}$ is from a tributary to Rio del Oso at the north end of the burned area (basin 241). It is not known if the estimated volumes of material are sufficient to dam watercourses or cause flooding, which could affect resources in the valleys downstream from the basins evaluated.

\section{Combined Relative Debris Flow Hazard Rankings}

Combined Relative Debris-Flow Hazard Rankings are produced by summing the estimated probability and volume ranking to illustrate those areas with the highest potential occurrence of debris flows of the largest volumes (Plate 3). The highest combined hazard rankings in the northern section of the burned area are predicted for basins tributary to Santa Clara Canyon, the Rio del Oso, and Vallecitos Creek (Plate 3). The watersheds of Peralta, Colle, Bland, Cochiti, Capulin, Alamo, and Frijoles Canyons in the southern section of the burned area also showed high Combined Relative Debris-Flow Hazard Ranking, as well as basins in Water Canyon, Guaje Canyon, and Los Alamos Canyon.

Santa Clara Canyon, in the northern part of the burn area, contains a spring used by the Santa Clara Pueblo for water supply and several recreational lakes. Debris flows in this area could affect human life, property, agriculture, and infrastructure at and downstream from the modeled basins at locations along the valley floor, including the Pueblo of Santa Clara, the Pueblo of San Ildefonso, and private lands. The high Combined Relative Debris-Flow Hazard Ranking areas that occur upstream from the City of Los Alamos could damage bridges and culverts along State Highway 4 and affect activities downstream in the City of Los Alamos and at Los Alamos National Laboratory. Similarly, debris flows in Peralta, Bland, Cochiti, and Alamo Canyons may also create hazardous conditions in locations downstream from the modeled basins along the valley floors and continuing towards their confluences with the Rio Grande. Such debris flows could potentially affect agricultural lands, water quality, infrastructure, property, and human life on lands of Cochiti Pueblo and Jemez Pueblo, and at Cochiti Lake.

Natural, archeological, and recreational resources within Bandelier National Monument could be affected by debris flows in and downstream of Capulin and Alamo Canyons as well as Frijoles Canyon, where the Visitor's Center is located. Most areas analyzed within Valles Caldera National Preserve were not found to have the highest Combined Relative Debris-Flow Hazard Ranking, because of the gentle slopes in the modeled basins.

\section{Limitations of Hazard Assessments}

This assessment provides estimates of debris flow probability, volume, and combined relative hazard ranking for drainage basins burned by the Las Conchas Fire in response to a 10-year-recurrence, 30-minute-duration rain storm. Larger, less frequent storms (for example, a 25-year recurrence storm) are likely to produce larger debris flows, and smaller storms (for example, a 2-year recurrence storm) could also trigger debris flows. Higher probabilities of 
debris flow than those shown on Plate 1 may exist within any subpart of the basins. Because not all rainstorms will be large enough to affect the entire burned area, debris flows may not be produced from all basins during a given storm.

It is important to note that the maps shown in Plates 1, 2, and 3 do not identify those areas that can be affected by debris flows as the material moves downstream from the basin outlets (Cannon and others, 2009). The upper watersheds in canyons of the Pajarito Plateau tend to have the highest debris-flow potential, but areas lower in the canyons would also be at risk if debris flows travel down the streambeds towards their confluence with the Rio Grande. Additionally, further investigation is needed to assess the potential for debris flows to affect structures at or downstream from basin outlets and to increase the threat of flooding downstream by damaging or blocking bridges or flood-mitigation structures.

Although landslides may be common on the flanks of the mesas in the Las Conchas Fire area (Goff and others, 2002), stability of these pre-existing landslide deposits was not evaluated in this study. In general, infiltration-dominated landslide processes that may occur in burned basins are substantially less frequent than are runoff-triggered debris flows, and the former contribute little to the total volume of material transported from the basin (Cannon and others, 2009). In addition, flash flooding unrelated to debris flows was not considered in this analysis, but remains a potential post-fire hazard.

The variables included in the models and used in this assessment are considered to directly affect debris-flow generation in the intermountain western United States. Conditions other than those used in the models (for example, the amount of sediment stored in a canyon) could also affect debris-flow production. Data necessary to evaluate such effects, however, are not readily available.

The potential for debris-flow activity decreases with time as revegetation stabilizes hillslopes and the supply of erodible material decreases in the canyons. However, if dry conditions prevent sufficient regrowth of vegetation, this recovery period will be longer. Similarly, if rainfall events for the first year are mild, recovery and stabilization of soil with vegetation may occur rapidly and diminish debris-flow hazards the following year. The assessment given here is estimated to be applicable for 2 to 3 years after the fire, depending on precipitation distribution (Cannon and others, 2009).

The maps in this report may be used to prioritize areas where emergency erosion mitigation or other protective measures may be needed prior to rainstorms within these basins, their outlets, or areas downstream from these basins. This assessment evaluates only postwildfire debris flows and does not consider hazards associated with flash floods; such hazards may remain for many years after a fire.

This work is preliminary and is subject to revision. It is being provided because of the need for timely "best science" information. The assessment herein is provided on the condition that neither the U.S. Geological Survey nor the United States Government may be held liable for any damages resulting from the authorized or unauthorized use of the assessment.

\section{Summary}

In June and July 2011, the Las Conchas Fire burned 157,000 acres (634 square kilometers) in the Jemez Mountains of north-central New Mexico (Plate 1). Nearby and coincident areas were burned during the La Mesa Fire of 1977, the Dome Fire of 1996, and the Cerro Grande Fire of 2000. Areas affected by the Las Conchas Fire include basins upstream from the City of Los Alamos and the Los Alamos National Laboratory; Cochiti Lake; archeological 
and recreational lands of Bandelier National Monument and Valles Caldera National Preserve; and the watersheds and lands of the Pueblos of Santa Clara, Cochiti, San Ildefonso, and Jemez. Basins within the burned area are now at risk of damage from postwildfire erosion hazards such as those associated with debris flows and flash floods.

A pair of empirical models developed from data collected in recently burned basins throughout the intermountain western United States was used to estimate the probability of occurrence and volume of debris flows for selected drainage basins within the Las Conchas Fire burn area in response to a 10-year-recurrence, 30-minute-duration rainstorm of $28.0 \mathrm{~mm}$.

Probabilities of debris flow greater than 80 percent were identified for two-thirds (67 percent) of the modeled basins. The highest probabilities occur in tributaries to Santa Clara Canyon and the Rio del Oso in the northeastern part of the burned area; basins in the Valles Caldera National Preserve; tributaries to Los Alamos and Guaje Canyons in the central part of the burned area; and tributaries to Peralta, Colle, Bland, Cochiti, Frijoles, Alamo, and Capulin Canyons in the south part of the burned area. Estimated debris-flow volumes ranged from 400 cubic meters $\left(\mathrm{m}^{3}\right)$ to greater than $72,000 \mathrm{~m}^{3}$. Drainage basins with relatively large estimated volumes (over 10,000 $\mathrm{m}^{3}$ ) include tributaries to Santa Clara Canyon, Rio del Oso, Vallecitos Creek, and Arroyo de la Plaza Larga in the northern part of the burn area; tributaries to Guaje, Water, and Los Alamos Canyons in the central section of the burn area; and tributaries to Peralta, Colle, Bland, Cochiti, Capulin, Alamo, and Frijoles Canyons in the southern part of the burn area. Basins with estimated debris-flow volumes greater than $40,000 \mathrm{~m}^{3}$ include a tributary to Santa Clara Canyon, basins in Water and Los Alamos Canyons, a basin tributary to Vallecitos Creek and a tributary to Rio del Oso. The Combined Relative Debris-Flow Hazard Ranking identifies the greatest threat from debris flows in Santa Clara Canyon and tributary basins to Rio del Oso and Vallecitos Creek in the north; in the watersheds of Peralta, Colle, Bland, Cochiti, Capulin, Alamo, and Frijoles Canyons to the south; and in Los Alamos, Guaje, and Water Canyons upstream from the City of Los Alamos.

Debris flows may directly affect the water supply for Santa Clara Pueblo as well as several recreational lakes, archeological resources in Bandelier National Monument, bridges and culverts along State Highway 4, and other roadways. The debris-flow probabilities and volumes estimated in response to the design storm may also indicate a potential for debris-flow effects to buildings, roads, bridges, culverts, agricultural lands, and reservoirs downstream from the burned area, such as those at the City of Los Alamos, the Los Alamos National Laboratory, the Pueblos of Santa Clara and Cochiti, and Cochiti Lake.

The maps presented here may be used to prioritize areas where emergency erosion mitigation or other protective measures may be needed prior to rainstorms within these basins, their outlets, or areas downstream from these basins within the 2 to 3 -year window of vulnerability.

\section{References Cited}

Bonnin, G.M., Martin, D., Lin, B., Parzybok, T., Yekta, M., and Riley, D., 2006, Precipitationfrequency atlas of the United States: Silver Spring, Md., National Weather Service, National Oceanic and Atmospheric Administration (NOAA) atlas 14, v. 1, version 4, accessed August 2011, at http://hdsc.nws.noaa.gov/hdsc/pfds/.

Cannon, S.H., and Reneau, S.L., 2000, Conditions for the generation of fire-related debris flows, Capulin Canyon, New Mexico: Earth Surface Processes and Landforms, v. 25, p. 1103-1121. 
Cannon, S.H., Gartner, J.E., Parrett, C., Parise, M., 2003, Wildfire-related debris-flow generation through episodic progressive sediment-bulking processes, western U.S.A., in Ricenmann, D., and Chen, C.-L., eds., International Conference on Debris-Flow Hazards MitigationMechanics, Prediction, and Assessment, $3^{\text {rd }}$, Davos, Switzerland, 10-12 September 2003, Proceedings: Millpress, Rotterdam, p. 71-82.

Cannon, S.H., and Gartner, J.E., 2005, Wildfire-related debris flow from a hazards perspective, chapter 15, of Jakob, Matthias, and Hungr, Oldrich, eds., Debris-flow hazards and related phenomena: Chichester, U.K., Springer-Praxis Books in Geophysical Sciences, p. 321-344.

Cannon, S.H., Gartner, J.E., and Michael, J.A., 2007, Methods for the emergency assessment of debris-flow hazards from basins burned by the fires of 2007, southern California: U.S. Geological Survey Open-File Report 2007-1384, 10 p.

Cannon, S.H., Gartner, J.E., Wilson, R.C., and Laber, J.L., 2008, Storm rainfall conditions for floods and debris flows from recently burned areas in southwestern Colorado and southern California: Geomorphology, v. 96, p. 250-269.

Cannon, S.H., Gartner, J.E., Rupert, M.G., Michael, J.A., Rea, A.H., and Parrett, C., 2009, Predicting the probability and volume of postwildfire debris flows in the intermountain western United States: Geological Society of America Bulletin, v. 122, p. 127-144.

DeBano, L.F., 1981, Water repellant soil-A state-of-the-art: U.S. Department of Agriculture, Forest Service, General Technical Report PSW-46, Berkeley, Calif., Pacific Southwest Forest and Range Experiment Station, $21 \mathrm{p}$.

DeGraff, J.V., Wagner, D., Gallegos, A.J., DeRose, M., Shannon, C. and Ellsworth, T. 2011, The remarkable occurrence of large rainfall-induced debris flows at two different locations on July 12, 2008, Sierra Nevada, California: Landslides, v. 8, no. 2, p. 343-353.

Doerr, S.H., Shakesby, R.A., and Walsh, R.P.D., 2000, Soil water repellency-Its causes, characteristics and hydro-geomorphological significance: Earth-Science Reviews v. 15, p. 33-65.

Gartner, J.E., Cannon, S.H., Bigio, E.R., Davis, N.K., Parrett, C., Pierce, K.L., Rupert, M.G., Thurston, B.L., Trebish, M.J., Garcia, S.P., and Rea, A.H., 2005, Compilation of data relating to the erosive response of 606 recently burned areas: U.S. Geological Survey Open-File Report 2005-1218. (Also available at http://pubs.usgs.gov/of/2005/1218/.)

Goff, F., Gardner, J.N., and Reneau, S.L., 2002, Geology of the Frijoles 7.5-min. quadrangle, Los Alamos and Sandoval Counties, New Mexico: New Mexico Bureau of Geology and Mineral Resources, OF-GM 42, scale 1:24,000.

Goff, F., Reneau, S.L., Goff, C.J., Gardner, J.N., Drakos, P., and Katzman, D., 2005, Geology of the Bland quadrangle, Los Alamos and Sandoval Counties, New Mexico: New Mexico Bureau of Geology and Mineral Resources, OF-GM 112, scale 1:24,000.

Helsel, D.R., and Hirsch, R.M., 2002, Statistical methods in water resources: U.S. Geological Survey Techniques of Water-Resources Investigations, book 4, chap. A3, 510 p.

InciWeb, Incident Information System, 2011, Incident Information, Las Conchas, accessed August 2011 at http://www.inciweb.org/incident/2385/.

Kean, J.W., Staley, D.M., and Cannon, S.H., 2011, In situ measurements of post-fire debris flows in southern California - Comparisons of the timing and magnitude of 24 debris-flow events with rainfall and soil moisture conditions: Journal of Geophysical Research, doi:10.1029/2011JF002005. 
Kempter, K.A., and Kelley, S., 2002, Geology of the Guaje Mountain 7.5-min. quadrangle, Los Alamos and Sandoval Counties, New Mexico: New Mexico Bureau of Geology and Mineral Resources, Open-File Geologic Map 55, scale 1:24,000.

Letey, J., 2001, Causes and consequences of fire-induced soil water repellency: Hydrological Processes, v. 15, p. 2867-2875.

Melton, M.A., 1965, The geomorphic and paleoclimatic significance of alluvial deposits in southern Arizona: Journal of Geology, v. 73, p. 1-38.

Meyer, G.A., 2002, Fire in western conifer forests-Geomorphic and ecologic processes and climatic drivers: Geological Society of America Abstracts with Programs, v. 34, p. 46.

Moody, J.A., and Martin, D.A., 2001a, Initial hydrologic and geomorphic response following a wildfire in the Colorado Front Range: Earth Surface Processes and Landforms, v. 26, p. 1049-1070.

Moody, J.A., and Martin, D.A., 2001b, Hydrologic and sedimentologic response of two burned watersheds in Colorado: U.S. Geological Survey Water-Resources Investigations Report 01-4122, $138 \mathrm{p}$.

Romkens, M.J.M., Prasad, S.N., and Whisler, F.D., 1990, Surface sealing and infiltration, chapter 5, of Anderson, M.G., and Burt, T.P. eds., Process studies in hillslope hydrology: New York, John Wiley and Sons, p. 127-172.

Schwartz, G.E., and Alexander, R.B., 1995, Soils data for the conterminous United States derived from the NRCS State Soil Geographic (STATSGO) Database: U.S. Geological Survey Open-File Report 95-449, accessed July, 2011, at http://water.usgs.gov/lookup/getspatial?/ussoils.

Smith, R.I., Bailey, R.A., and Ross, C.S., 1970, Geologic map of the Jemez Mountains, New Mexico: U.S. Geological Survey, Miscellaneous Geological Investigations Map I-571, 1 sheet, scale 1:125,000.

U.S. Department of Agriculture Forest Service, 2011, Remote Sensing Applications CenterBAER Imagery Support Data Download: Washington, D.C., U.S. Department of Agriculture Forest Service, accessed August, 2011, at http://activefiremaps.fs.fed.us/baer/download.php.

U.S. Geological Survey, 2011, Seamless Data Warehouse, National Elevation Dataset 1/9 Arc-Second, accessed August 2011 at http://seamless.usgs.gov.

Veenhuis, J.E., 2002, Effects of wildfire on the hydrology of Capulin and Rito De Los Frijoles Canyons, Bandelier National Monument, New Mexico: U.S. Geological Survey WaterResources Investigations Report 02-4152, 39 p. (Also available at http://pubs.usgs.gov/wri/wri02-4152/.)

Wells, H.G., 1987, The effects of fire on the generation of debris flows in southern California, in Costa, J.E., and Wieczorek, G.F., eds., Debris flows/avalanches_-Process, recognition, and mitigation: Geological Society of America, Reviews in Engineering Geology, v. 7, p. 105-114.

Woods, S.W., Birkas, A., and Ahl, R., 2006, Spatial variability of soil hydrophobicity after wildfires in Montana and Colorado: Geomorphology, v. 86, p. 465-479. 